\title{
Analisis Faktor-Faktor Yang Berpengaruh Pada Keputusan Pembelian Produk Kosmetik Halal
}

\author{
Eni Mulati ${ }^{1}$, Budi Utomo ${ }^{2}$ \\ ${ }^{\text {I} P r o g r a m ~ S t u d i ~ E k o n o m i ~ S y a r i a h ~, ~ I n s t i t u t ~ A g a m a ~ I s l a m ~ N e g e r i ~ S a l a t i g a, ~ J l . ~ T e n t a r a ~ P e l a j a r ~ N o ~ 2, ~ S a l a t i g a, ~} 50715$ \\ E-mail: enimulatijung99@gmail.com \\ ${ }^{2}$ Fakultas Ekonomi dan Bisnis Islam, Institut Agama Islam Negeri Salatiga, Jl. Tentara Pelajar No 2, Salatiga, 50715 \\ E-mail: budiutomo@iainsalatiga.ac.id
}

\begin{abstract}
The purpose of this research is to find out the influence of product knowledge, religiosity, and Islamic advertising ethics on purchasing decisions with purchase intention as intervening variable. Data was collected by distributing questionnaire to 100 respondents of consumers of Wardah product cosmetics in Salatiga with purposive sampling method. The data obtained were processed using SPSS 23 analysis tools. Based on the t-test, the results showed that partially product knowledge had no effect on purchasing decision, then religiosity partially had no effect on purchasing decisions. While consumer buying interest partially has a significant effect on purchasing decisions. Based on the results of the path analysis test, it show that buying interest doesn't have a mediating effect on the influence of religiosity on purchasing decisions. Then buying interest has a mediating effect on the influence of product knowledge and Islamic advertising ethics on each purchase decision.
\end{abstract}

Keywords—: Product knowledge; religiosity; islamic advertising ethics, buying interest; purchase decision.

\section{PENDAHULUAN}

Saat ini halal lifestyle berkembang di beberapa negara terutama di negara dengan penduduk mayoritas beragama islam, salah satunya yaitu negara Indonesia. Menurut Adinugraha \& Sartika (2019) tren halal lifestyle adalah sebuah tren gaya hidup atau pula hidup sehari-hari yang didasarkan atas prinsip dan nilai ajaran agama islam. Dapat disimpulkan bahwa tren halal life stlyle adalah semua kegiatan dalam kehidupan sehari-hari dilakukan sesuai dengan apa yang diajarkan dalam agama islam. Salah satunya yaitu dalam hal menkonsumsi suatu produk, di mana dalam agama islam kita dilarang untuk menkonsumsi barang yang haram.

Dalam menkonsumsi suatu barang pastilah akan membutuhkan suatu keputusan pembelian, dimana proses pengambilan keputusan ini disebut juga perilaku konsumen. Menurut Adiba et al (2018) banyak faktor yang dapat mempengaruhi perilaku konsumen atau keputusan pembelian ini, diantaranya ialah yang akan dibahas dalam penelitian ini yaitu product knowledge, religiosity, dan islamic advertising ethics serta minat beli. Telah banyak penelitian yang dilakukan mengenai pengaruh product knowledge, religiosity, islamic advertising ethics serta minat beli terhadap keputusan pembelian, diantaranya yaitu penelitian yang dilakukan oleh Solihin (2020) yang menyatakan bahwa minat memiliki pengaruh yang signifikan terhadap keputusan pembelian. Namun berbeda dengan penelitian yang dilakukan oleh Ulya (2020) yang menyatakan bahwa minat beli tidak memiliki pengaruh terhadap keputusan pembelian.

Penelitian selanjutnya dilakukan oleh Nuraeni (2020) yang menyatakan bahwa product knowledge memiliki pengaruh yang signifikan terhadap keputusan pembelian. Berbeda dengan hasil penelitian yang dilakukan oleh Mutiara \& Syahputra (2018) yang menyatakan bahwa product knowledge tidak memiliki pengaruh terhadap keputusan pembelian. Selanjutnya adalah penelitian yang dilakukan oleh Imamuddin (2017) yang menyatakan bahwa religiosity memiliki pengaruh yang signifikan terhadap keputusan pembelian. Berbeda dengan penelitian yang dilakukan oleh (Pradani \& Iriani, 2018) yang menyatakan bahwa religiosity tidak memiliki pengaruh terhadap keputusan pembelian.

Penelitian terdahulu yang dilakukan oleh Zulkifli, et al (2019) menunjukan bahwa etika periklanan islami atau islamic advertising ethics dapat mempengaruh keputusan konsumen dalam membeli suatu produk. Namun berbeda dengan penelitian yang dilakukan oleh Ghani \& Ahmad (2015) yang menunjukan bahwa etika periklanan islami atau islamic advertising ethics tidak berpengaruh terhadap keputusan pembelian.

Adanya fenomen tren halal lifestyle ini secara tidak langsung akan membentuk kesadaran konsumen akan kehalalan suatu produk, maka hal tersebut akan berdampak pada proses pengambilan keputusan pembelian, yaitu dengan mempertimbangkan kehalalan suatu produk termasuk dalam pengambilan keputusan pembelian suatu produk kosmetik. Salah satu merek kosmetik yang popular di Indonesia adalah kosmetik wardah. Berikut adalah daftar top brand kosmetik wardah dari tahun 2016-2020.

Tabel 1. Top brand index wardah tahun 2016-2020

\begin{tabular}{|c|c|c|c|c|c|c|}
\hline No & Merek & 2016 & 2017 & 2018 & 2019 & 2020 \\
\hline 1 & Wardah & $22,3 \%$ & $26,7 \%$ & $41,4 \%$ & $34,3 \%$ & $31,0 \%$ \\
\hline 2 & Garnier & $15,0 \%$ & $14,3 \%$ & $7,8 \%$ & $13,5 \%$ & $11,6 \%$ \\
\hline 3 & Olay & $5,5 \%$ & $6,5 \%$ & $14,0 \%$ & $7,0 \%$ & $5,1 \%$ \\
\hline
\end{tabular}


Website : http://ekomaks.unmermadiun.ac.id

Dari Tabel 1 dapat diketahui bahwa penjulan kosmetik wardah selama lima tahun ini mengalami fluktuasi, namun masih dapat dikatakan dalam prosentase yang tinggi. Sehingga dapat dikatakan bahwa produk kosmetik wardah ini popular atau banyak diminati dikalangan masyarakat, tak terkecuali masyarakat yang berada di Kota Salatiga. Sehingga permasalahan dalam penelitian ini adalah bagaimana product knowledge, religiosity, islamic advertising ethics serta minat beli berpengaruh terhadap keputusan pembelian kosmetik halal (wardah) di Kota Salatiga dengan minat beli sebagai variabel mediasi.

Penelitian ini memiliki tujuan untuk mengetahui pengaruh dari product knowledge, religiosity, islamic advertising ethics terhadap keputusan pembelian produk kosmetik halal dan untuk mengetahui pengaruh mediasi dari minat beli terhadap keputusan pembelian produk kosmetik. Penelitian ini memilih produk kosmetik merek wardah sebagai objek penelitian.

\section{TINJAUAN TEORITIS}

\section{A. Product Knowledge}

Menurut Sumarwan (2014) pengetahuan produk atau product knowledge merupakan sekumpulan infotmasi mengenai suatu produk yang terdiri dari kategori produk, merek, atribut produk, harga produk, serta kepercayaan mengenai produk. Menurut Peter \& Olson (2010), konsumen mempunyai macam atau tipe pengetahuan yang berbeda-beda, dan konsumen dapat menggunakan pengetahuan tersebut untuk memahami informasi baru dan memutuskan pembelian pada suatu produk. Ada tiga jenis pengetahuan produk, diantaranya yaitu Peter \& Olson (2010):

1. Pengetahuan tentang atribut produk

Pengetahuan tentang atribut produk ini mencakup pengetahuan tentang karaktersitik fisik dari suatu produk seperti label dan merek produk

2. Pengetahuan tentang manfaat produk

Pengetahuan tentang manfaat produk sangat penting bagi konsumen dalam memutuskan pembelian. Manfaat produk dibagi menjadi dua yaitu manfaat fungsional atau manfaat nyata yang didapat konsumen secara langsung setelah mengkonsumsi suatu produk, dan manfaat yang kedua yaitu manfaat psikologis atau manfaat internal yang dirasakan berdasarkan penilaian pribadi.

3. Pengetahuan tentang kepuasan yang didapatkan setelah menkonsumsi suatu produk

Seorang konsumen setelah mengkonsumsi suatu produk, maka akan merasakan dampak atau efek yang ditimbulkan oleh produk tersebut. Dapat dikatakan puas apabila apa yang seorang konsumen rasakan sesuai atau bahkan melebihi apa yang diharapkan dari produk tersebut.

\section{B. Religiosity}

Agama islam merupakan agama yang menjangkau semua aspek kehidupan termasuk dalam hal konsumsi. Agama dapat diwujudkan dalam berbagai aspek kehidupan manusia. Religiusitas atau religiosity adalah variabel mendasar yang menentukan perilaku seseorang yang hal tersebut dapat mempengaruhi perilaku konsumen (Sudarti \& Ulum, 2019). Menurut Glock \& Stark (1965) ada lima dimensi dalam religiusitas, yaitu:

1) Dimensi keyakinan

Dimensi ini menggambarkan seberapa tinggi kadar keyakinan yang dimiliki seseorang terhadap ajaran yang ada dalam agamanya.

2) Dimensi praktik agama

Dimensi ini menggambarkan sikap dan tindakan seseorang dalam ketaatan dan kepatuhannya terhadap ajaran agamanya.

3) Dimensi pengalaman

Dalam dimensi ini mencakup pada pengalaman, perasaan, dan harapan.

4) Dimensi pengetahuan agama

Pada dimensi ini menggambarkan tingkat pengetahuan seseorang mengenai ajaran-ajaran pokok dalam agamanya.

5) Dimensi pengamalan

Dimensi ini menunjukkan perilaku seseorang yang didorong atau termotivasi oleh ajaran-ajaran yang ada dalam agamanya, seperti saling menghargai, tolong menolong, bekerjasama dan lain sebagainya.

\section{Islamic Advertising Ethics}

Iklan adalah bentuk penyampaian informasi atau promosi barang dan jasa secara non personal oleh suatu sponsor tertentu yang memerlukan pembayaran. Iklan adalah salah satu cara produsen dalam mengenalkan dan menawarkan produknya kepada konsumen. Beberapa tujuan dari iklan yaitu untuk memberikan informasi serta menawarkan produk kepada konsumen, tujuan lainnya adalah untuk mempertahankan merek, kemudian untuk meyakinkan konsumen akan produk tersebut, dan lain sebagainya (Nurfadilah et al., 2020).

Etika merupakan prinsip serta norma-norma yang wajib ditegakkan yang dalam artian bisnis, etika adalah prinsip dan norma yang harus dilakukan oleh semua pelaku bisnis, baik dalam bertransaksi, berperilaku dan dalam berelasi bisnis (Nurfadilah et al., 2020). Etika ini juga sangat diperlukan dalam periklanan, karena dengan adanya etika dalam periklanan adalah salah satu bentuk perlindungan konsumen. Iklan yang disampaikan dengan jujur dan tidak mendatangkan kerugian bagi konsumen adalah salah satu bentuk penerapan dari etika periklanan tersebut. 
Website : http://ekomaks.unmermadiun.ac.id

Dalam persfektif islam etika perikalanan islami atau islamic advertising ethics adalah bentuk komunikasi pemasaran secara komersial maupun layanan masyarakat yang disampaikan berlandaskan nilai-nilai islam yang bersumber dari Al-Qur'an dan Hadits (Nurfadilah et al., 2020). Menurut Mutaqin (2013) konsep periklanan dalam islam adalah sebagai berikut:

a. Tujuan dan macam iklan, tujuan iklan diantaranya ialah, persuasif informatif dan pengingat. Dalam perspektif islam iklan harus didasarkan pada sifat shiddiq, amanah dan dapat dipercaya.

b. Kegunaan iklan, dalam ekonomi islam kegunaan iklan harus dilandaskan pada sifat shiddiq dan amanah.

c. Tingkatan iklan, ada dua tingkatan pada iklan yaitu tingkat informatif dan tingkat merubah sikap konsumen. Referensi iklan, ada 2 macam iklan berdasarkan referensinya yaitu respresentatif atau referensi realita sosial, dan yang kedua yaitu simulasi atau tidak memiliki referensi realita sosial.

\section{Minat Beli}

Minat beli ialah perilaku konsumen yang timbul sebagai respon terhadap suatu barang yang menunjukan minat atau niat seseorang untuk membeli barang tersebut (Solihin, 2020). Minat beli dipengaruhi pula oleh faktor-faktor eksternal diantaranya adalah kesadaran kebutuhan, pengenalan dan evaluasi produk. Menurut Ferdinand (2011) minat beli dapat diidentifikasi melalui beberapa indikator berikut:

a) Minat transaksional adalah kecenderungan seseorang untuk membeli produk

b) Minat referensial kecenderungan seseorang untuk merekomendasikan produk kepada orang lain

c) Minat preferensial adalah minat untuk menunjukkan perilaku orang-orang yang memiliki preferensi terhadap suatu produk.

d) Minat eksploratif adalah minat yang menunjukkan perilaku seseorang yang selama ini mencari informasi yang mendukung sifat positif dari suatu produk.

E. Keputusan Pembelian

Keputusan pembelian adalah studi tentang bagaimana seseorang memilih, membeli, menggunakan atau tidak lagi menggunakan suatu produk (Adiba et al., 2018). Keputusan konsumen adalah proses yang dilakukan oleh konsumen dengan melalui tahapan-tahapan tertentu. Tahapan-tahapan tersebut ialah (Kotler \& Keller, 2012):

1. Pengenalan masalah, dari timbulnya masalah kebutuhan tersebut konsumen akan termotivasi untuk menyelesaikan masalahnya dengan memenuhi keubutuhan tersebut.

2. Pencarian informasi, tahap kedua yaitu mencari informasi produk yang dibutuhkan untuk memenuhi kebutuhannya.

3. Evaluasi alternatif, pada tahap ini konsumen mengevaluasi satu per satu produk yang menjadi alternatif pilihan sebelum melakukan pembelian.

4. Keputusan pembelian, pada tahap ini konsumen telah benar-benar memilih dan membeli produk yang sesuai dengan kebutuhannya.

5. Evaluasi pasca pembelian, pada tahap ini konsumen akan menunjukkan perilaku menyukai atau tidak menyukai suatu produk setelah membeli dan menggunakan produk tersebut.

\section{III.METODE PENELITIAN}

\section{A. Jenis Penelitian}

Penelitian ini adalah jenis penelitian kuantitatif yang bertujuan untuk mengetahui pengaruh variabel independen terhadap variabel dependen.

\section{B. Populasi dan Sampel Penelitian}

Populasi dalam penelitian ini ialah konsumen kosmetik wardah yang berada di Kota Salatiga. Kemudian sampel dalam penelitian ini adalah sebanyak 100 sampel.

\section{Sampel}

Dalam penelitian ini, pengambilan sampel menggunakan teknik purposive sampling, yaitu teknik pengambilan sampel dengan kriteria tertentu yang telah ditentukan oleh peneliti. Dalam penelitian ini kriteria tersebut diantaranya adalah berdomisili di Kota Salatiga dan pernah atau sedang menggunakan produk wardah.

\section{Teknik Pengumpulan Data}

Pengumpulan data dalam penelitian ini dengan menyebarkan angket atau kuesioner kepada subjek atau responden penelitian yaitu konsumen kosmetik wardah yang berada di Kota Salatiga.

\section{E. Teknik Analisis Data}

Teknik analisis data pada penelitian ini yaitu menggunakan uji instrumen yang mencakup uji reliabilitas dan uji validitas, kemudian uji selanjutnya yaitu uji hipotesis menggunakan analisis jalur atau path analysis.

\section{IV.ANALISIS DAN PEMBAHASAN}

\section{A. Uji Instrumen}

Untuk mengetahui valid tidaknya item pernyataan dalam kuesioner digunakan uji validitas. Dasar untuk mengukur validitasnya adalah dengan melakukan perbandingan nilai pearson correlation atau $r$ hitung pada koefisien korelasi pada tiap item pernyataan dalam kuesioner. Jika nilai $\mathrm{r}$ hitung lebih besar dari $\mathrm{r}$ tabel maka item pernyataan dalam kuesioner dinyatakan valid (Ghozali, 2011). Berdasarkan hasil uji validitias, semua item pernyataan kuesioner dalam penelitian ini dinyatakan valid, dengan nilai $r$ tabel sebesar 0,195 dengan tingkat signifikansi 5\%. 
Reliabilitas ialah alat ukur kuesioner dan indikator dari suatu variabel. Jika jawaban seorang responden konsisten dan stabil sepanjang waktu, maka dapat dikatakan kuesioner dan indikator tersebut reliabel. Dasar penentuan dalam uji reliabilitas adalah dengan melihat nilai cronbach's alpha. Jika nilai cornbach's alpha lebih dari 0,60 maka dapat dikatakan reliabel (Ghozali, 2011). Berdasarkan uji reliabilitias, variabel-variabel dalam penelitian ini reliabel, dengan nilai cronbach's alpha yang lebih dari 0,60 .

\section{B. Uji Statistik}

1) $U j i T$

Berikut adalah hasil uji t pada penelitian ini:

Tabel 2. Hasil uji t persamaan 1 Coefficients $^{\mathbf{a}}$

\begin{tabular}{|c|c|c|c|c|c|}
\hline \multirow[b]{2}{*}{ Model } & \multicolumn{2}{|c|}{$\begin{array}{c}\text { Unstandardized } \\
\text { Coefficients }\end{array}$} & \multirow{2}{*}{$\begin{array}{c}\begin{array}{c}\text { Standardized } \\
\text { Coefficients }\end{array} \\
\text { Beta }\end{array}$} & \multirow[b]{2}{*}{$\mathrm{t}$} & \multirow[b]{2}{*}{ Sig. } \\
\hline & $\mathrm{B}$ & Std. Error & & & \\
\hline (Constant) & $-0,8.281$ & 3,018 & & $-2,744$ & 0,007 \\
\hline Product knowledge & 0,664 & 0,118 & 0,385 & 5,632 & 0,000 \\
\hline Religiusity & 0,008 & 0,076 & $-0,008$ & $-0,102$ & 0,919 \\
\hline $\begin{array}{l}\text { Islamic advertising } \\
\text { ethics }\end{array}$ & 0,210 & 0,028 & 0,576 & 7,590 & 0,000 \\
\hline
\end{tabular}

a. Dependent Variable: Minat_beli

Sumber: Data primer yang diolah, 2021

Berdasarkan Table 2, dapat diketahui bahwa hasil uji t dalam penelitian ini adalah sebagai berikut:

a. Variabel product knowledge memiliki nilai signifikansi sebesar 0,000 lebih kecil dari 0,05.

b.Variabel religiosity memiliki nilai signifikansi sebesar 0,919 lebih besar dari 0,05.

c. Variabel islamic advertising ethics memiliki nilai signifikansi sebesar 0,000 kurang dari 0,05.

Tabel 3. Hasil uji t persamaan 2 Coefficients $^{\mathrm{a}}$

\begin{tabular}{|l|r|r|r|r|r|}
\hline & \multicolumn{2}{|c|}{$\begin{array}{c}\text { Unstandardized } \\
\text { Coefficients }\end{array}$} & $\begin{array}{c}\text { Standardized } \\
\text { Coefficients }\end{array}$ & \multirow{2}{*}{} \\
\cline { 2 - 4 } Model & \multicolumn{1}{|c|}{$\mathrm{B}$} & $\begin{array}{c}\text { Std. } \\
\text { Error }\end{array}$ & Beta & $\mathrm{t}$ & \multicolumn{1}{c|}{ Sig. } \\
\hline (Constant) & 8,995 & 3,554 & & 2,531 & 0,013 \\
Product knowledge & 0,000 & 0,154 & 0,000 & 0,002 & 0,998 \\
Religiusity & 0,115 & 0,087 & 0,110 & 1,331 & 0,186 \\
Islamic advertising & 0,073 & 0,040 & 0,191 & 1,852 & 0,067 \\
ethics & 0,608 & 0,116 & 0,575 & 5,252 & 0,000 \\
Minat beli & & & & \\
\hline
\end{tabular}

a. Dependent Variable: Keputusan_Pembelian

Sumber: Data primer yang diolah, 2021

Berdasarkan Tabel 3, dapat diketahui hasil uji t dalam penelitian ini dengan kesimpulan sebagai berikut:

a. Variabel product knowledge memiliki nilai signifikan 0,998 lebih dari 0,05.

b.Variabel religiosity memiliki nilai signifikan 0, 186 lebih dari 0,05.

c. Variabel islamic advertising ethics memiliki nilai signifikan 0,067 lebih dari 0,05.

d.Variabel minat beli memiliki nilai signifikan sebesar 0,000 lebih kecil dari 0,05.

2) $U j i F$

Berikut adalah hasil dari uji $\mathrm{F}$ pada penelitian ini:

Tabel 4. Hasil uji F
\begin{tabular}{|l|r|r|r|r|l|}
\hline Model & Sum of Squares & \multicolumn{1}{|c|}{ df } & Mean Square & F & Sig. \\
\hline Regression & 1498,439 & 4 & 374,610 & 42,146 & $0,000^{\mathrm{b}}$ \\
Residual & 844,401 & 95 & 8,888 & & \\
Total & 2342,840 & 99 & & & \\
\hline
\end{tabular}

a. Dependent Variable: Keputusan Pembelian

b. Predictors: (Constant), Minat beli, Religiusity, Product knowledge, Islamic advertising_ethics

Sumber: Data primer yang diolah, 2021 
Website : http://ekomaks.unmermadiun.ac.id

Berdasarkan Tabel 4, dapat diketahui hasil dari uji $\mathrm{F}$ pada penelitian ini, yaitu menunjukkan nilai signifikan sebesar 0,000 yang lebih kecil dari 0,05. Hal ini menujukkan bahwa variabel independen pada penelitian ini memiliki pengaruh yang simultan atau berpengaruh secara bersama-sama pada keputusan pembelian.

3) Uji Koefisien Determinasi $\left(R^{2}\right)$

Berikut adalah hasil dari uji koefisien determinasi pada penelitian ini:

Tabel 5. Hasil uji koefisen determinasi $\left(R^{2}\right)$

Model Summary

\begin{tabular}{|l|r|r|r|r|}
\hline Model & $\mathrm{R}$ & R Square & Adjusted R Square & $\begin{array}{r}\text { Std. Error of } \\
\text { the Estimate }\end{array}$ \\
\hline 1 & $0,800^{\mathrm{a}}$ & 0,640 & 0,624 & 2,981 \\
\hline
\end{tabular}

a. Predictors: (Constant), Minat beli, Religiusity, Product knowledge, Islamic advertising ethics

Sumber: Data primer yang diolah, 2021

Berdasarkan Tabel 5 dapat diketahui hasil uji koefisien determinasi dalam penelitian ini dengan keterangan sebagai berikut:

a. Nilai koefisien korelasi (R) menunjukan angka 0,800 sehingga disimpulkan bahwa nilai $\mathrm{R}$ mendekati angka 1 . Maka dapat disimpulkan ada hubungan yang kuat antar variabel independen dengan variabel dependen.

b.Nilai koefisien determinasi $\left(\mathrm{R}^{2}\right)$ menunjukkan angka 0,624 yang dapat diartikaan bahwa variabel independen memberikan kontribusi pengaruh terhadap variabel dependen sebesar 62,4\% sedangkan 37,6\% dipengaruhi oleh variabel lain yang tidak termasuk dalam penelitian ini.

\section{Path Analysis}

Untuk menguji hipotesis mediasi, maka digunakan analisis jalur atau path analysis. Berikut adalah hasil analisis jalur dalam penelitian ini:

1. Pengaruh Product Knowledge Terhadap Keputusan Pembelian Melalui Minat Beli

Untuk mengethaui pengaruh mediasinya, maka digunakan sobel test sebagai berikut:

$\mathrm{Sp} 4 \mathrm{p} 7=\sqrt{\mathrm{p}} 7^{2} \mathrm{Sp} 4^{2}+\mathrm{p} 4^{2} \mathrm{Sp} 7^{2}+\mathrm{Sp} 4^{2} \mathrm{Sp} 7^{2}$

Sp4p7 $=\sqrt{(0,608)^{2}(0,118)^{2}+(0,664)^{2}\left(0,116^{2}\right)+(0,118)^{2}(0,116)^{2}}$

Sp4p7 $=\sqrt{ } 0,0051+0,0059+0,0187$

$\mathrm{Sp} 4 \mathrm{p} 7=\sqrt{ } 0,0297$

Sp4p7 = 0,1723

Dari niali Sp4p7 dapat dihitung t statistik pengaruh mediasi dengan menggunakan rumus:

$\mathrm{t}=\mathrm{p} 4 \mathrm{p} 7: \mathrm{Sp} 4 \mathrm{p} 7$

$=0,403712: 0,1723$

$=2,342$

Berdasarkan nilai t hitung diatas yaitu 2,3430 yang menunjukan lebih dari nilai t tabel 1,66055 dengan tingkat signifikan 5\%.

2. Pengaruh Religiosity Terhadap Keputusan Pembelian Keputusan Pembelian Melalui Minat Beli

Untuk mengetahui pengaruh mediasinya, maka digunakan rumus sobel test sebagai berikut:

$\mathrm{Sp} 5 \mathrm{p} 7=\sqrt{\mathrm{p}} 7^{2} \mathrm{Sp} 5^{2}+\mathrm{p} 5^{2} \mathrm{Sp} 7^{2}+\mathrm{Sp} 5^{2} \mathrm{Sp} 7^{2}$

Sp5p7 $=\sqrt{(0,608)^{2}(0,0076)^{2}+(-0,008)^{2}(0,116)^{2}+(0,0076)^{2}(0,116)^{2}}$

Sp5p7 $=\sqrt{0,2135}+0,00000086+0,0077$

Sp5p7 $=\sqrt{ } 0,2212=0,4703$

Dari nilai Sp5p7 diatas, maka dapat dihitung t statisitk pengaruh mediasi dengan menggunakan rumus:

$\mathrm{t}=\mathrm{P} 2 \mathrm{P} 7: \mathrm{Sp} 2 \mathrm{p} 7$

$=0,004864: 0,4703$

$=0,0103$

Berdasarkan nilai ti hitung diatas yaitu 0,0103 yang menunjukan kurang dari t tabel 1,66055 dengan signifikansi $5 \%$.

3. Pengaruh Islamic Advertising Ethics Terhadap Keputusan Pembelian Melalui Minat Beli

Untuk mengetahui pengaruh mediasinya, maka digunakan rumus sobel test sebagai berikut:

$\mathrm{Sp} 6 \mathrm{p} 7=\sqrt{\mathrm{p}} 7^{2} \mathrm{Sp} 6^{2}+\mathrm{p} 6^{2} \mathrm{Sp} 7^{2}+\mathrm{Sp} 6^{2} \mathrm{Sp} 7^{2}$

Sp6p7 $=\sqrt{(0,608)^{2}(0,028)^{2}+(0,210)^{2}(0,116)^{2}+(0,028)^{2}(0,116)^{2}}$

Sp6p7 $=\sqrt{0,00028}+0,00059+0,000010$

Sp6p7 $=\sqrt{ } 0,00088$

Sp6p7 $=0,02964$

Dari nilai Sp6p7 dapat dihitung t statistik menggunakan rumus sebagai berikut:

$\mathrm{t}=$ P6P7 : Sp6p7

$=0,12768: 0,02964$

$=4,3076$

Dari nilai t hitung diatas yaitu 4,3076 yang menunjukan lebih dari t tabel 1,66055 dengan signifikansi 5\%.

A. Pengaruh Product Knowledge Terhadap Keputusan Pembelian 
Website : http://ekomaks.unmermadiun.ac.id

Berdasarkan hasil uji t yang telah dilakukan sebelumnya, variabel product knowledge menunjukkan nilai signifikansi 0,998 lebih dari 0,05. Sehingga dapat disimpulkan bahwa variabel product knowledge tidak memiliki pengaruh terhadap keputusan konsumen. Hal ini menunjukkan bahwa pengetahuan produk yang dimiliki oleh responden tidak menjadi alasan utama mereka dalam memutuskan pembelian suatu produk kosmetik. Banyak faktor yang dapat mempengaruhi keputusan konsumen. Menurut Kotler \& Keller (2009) salah satu faktor yang mempengaruhi keputusan seorang konsumen adalah faktor pribadi dari konsumen tersebut, dimana faktor pribadi tersebut meliputi pekerjaan, keadaan ekonomi, gaya hidup, dan lain sebagainya. Maka hipotesis pengaruh product knowledge terhadap keputusan pembelian dengan minat beli sebagai variabel intervening ditolak. Hasil penelitian ini relevan dengan peneltian sebelumnya yang dilakukan oleh Mutiara \& Syahputra (2018) dan Mahendra (2020) yang menyatakan bahwa pengetahuan produk tidak berpengaruh pada keputusan pembelian.

\section{B. Pengaruh Religiosity Terhadap Keputusan Pembelian}

Berdasarkan uji t yang telah dilakukan sebelumnya, variabel religiosity menunjukkan nilai signifikansi sebesar 0,186 lebih dari 0,05. Maka didapatkan kesimpulan bahwa variabel religiosity tidak mempunyai pengaruh terhadap keputusan pembelian. Hal ini menunjukkan bahwa tingkat religiusitas responden tidak menjadi hal yang utama dalam memilih dan membeli produk kosmetik. Menurut Peter \& Olson (2010) ada faktor yang disebut dengan pengaruh tujuan akhir, dimana tujuan akhir ini memiliki dua jenis, pertama yaitu tujuan optimalisasi dan yang kedua yaitu tujuan kepuasan. Sehingga dapat disimpulkan bahwa hipotesis pengaruh religiosity terhadap keputusan pembelian ditolak. Hasil penelitian ini relevan dengan penelitian sebelumnya yang dilakukan oleh Safitri (2019) dan Adiba et al (2018) yang menyatakan bahwa religiusitas tidak berpengaruh terhadap keputusan pembelian.

\section{Pengaruh Islamic Advertising Ethics Terhadap Keputusan Pembelian}

Berdasarkan hasil uji t, variabel islamic advertising ethics menunjukkan nilai signifikansi sebesar 0,067 lebih dari 0,05. Sehingga dapat diartikan bahwa tidak terdapat pengaruh antara islamic advertising ethics terhadap keputusan konsumen. Ada faktor lain yang dapat mempengaruhi keputusan seorang konsumen. Faktor tersebut ialah resiko fungsional dimana konsumen mempertimbangkan kegunaan dan manfaat dari suatu produk, apakah sesuai dengan yang diharapkan atau tidak, dengan kata lain konsumen lebih cenderung mempertimbangkan faktor kecocokan, kualitas serta manfaat dari suatu produk dibandingkan dengan etika perilklanan dari produk tersebut. Sehingga hipotesis pengaruh islamic advertising ethics terhadap keputusan pembelian ditolak. Hasil ini relevan dengan penelitian sebelumnya yang dilakukan oleh Cader (2017) yang menunjukkan bahwa etika periklanan islami tidak memiliki pengaruh pada keputusan pembelian.

\section{Pengaruh Product Knowledge Terhadap Minat Beli}

Berdasarkan uji t, variabel product knowledge menunjukkan nilai signifikansi yaitu 0,000 lebih kecil dari 0,05. Maka dapat disimpulkan bahwa variabel product knowledge memiliki pengaruh yang signifikan terhadap minat beli. Hal ini menujukkan bahwa semakin responden mengetahui tentang suatu produk maka minat beli responden akan produk tersebut semakin meningkat. Sehingga hipotesis pengaruh product knowledge terhadap minat beli diterima. Hasil ini relevan dengan penelitian sebelumnya yang dilakukan oleh Nasution (2020) dan Maharani \& Silvia (2019) yang menunjukkan bahwa variabel pengetahuan produk mempengaruhi minat beli konsumen.

\section{E. Pengaruh Religiosity Terhadap Minat Beli}

Berdasarkan hasil uji t, variabel religiosity menunjukkan nilai signifikansi sebesar 0,919 lebih dari 0,05. Sehingga dapat disimpulkan bahwa religiusitas tidak memiliki pengaruh terhadap minat beli konsumen. Hal ini menujukkan bahwa tingkat religiusitas tidak terlalu mempengaruhi miant beli responden terhadap suatu produk kosmetik. Sehingga hipotesis pengaruh religiosity terhadap minat beli ditolak. Hasil penelitian ini relevan dengan hasil penelitian sebelumnya yang dilakukan oleh Ikhsan \& Sukardi (2020) dan Maghfiroh (2018) yang menunjukkan bahwa variabel religiusitas tidak berpengaruh terhadap minat beli konsumen.

\section{F. Pengaruh Islamic Advertising Ethics Terhadap Minat Beli}

Berdasarkan hasil uji t, variabel islamic advertising ethics menunjukkan nilai signifikansi sebesar 0,000 lebih kecil dari 0,05. Maka dapat disimpulkan bahwa islamic advertising ethics memiliki pengaruh yang signifikan terhadap minat beli konsumen. Hal ini menunjukkan bahwa semakin baik etika periklanan suatu produk kosmetik yang ditayangkan dan sesuai dengan etika islami maka akan memberikan pengaruh yang berarti pada minat beli konsumen. Sehingga hipotesis pengaruh islamic advertising ethics terhadap minat beli diterima. Hasil penelitian ini relevan dengan hasil penelitian sebelumnya yang dilakukan oleh Ulfah (2020) dan Jayanegara \& Najib (2020) yang menunjukkan bahwa variabel etika periklanan islami memiliki pengaruh terhadap minat beli konsumen.

\section{G. Pengaruh Minat Beli Terhadap Keputusan Pembelian}

Berdasarkan hasil uji t, variabel minat beli menunjukkan nilai signifikansi sebesar 0,000 lebih kecil dari 0,05. Maka dapat disimpulkan bahwa minat beli memiliki pengaruh yang signifikan terhadap keputusan pembelian. Hal ini menunjukkan jika minat beli semakin meningkat, maka keputusan pembelian juga akan semakin meningkat atau dengan kata lain minat memberikan pengaruh yang berarti pada keputusan konsumen. Sehingga hipotesis pengaruh minat beli terhadap keputusan pembelian diterima. Hasil ini relevan dengan hasil penelitian sebelumnya yang dilakukan oleh Solihin (2020) dan Wulansari (2020) yang menunjukkan bahwa variabel minat berpengaruh terhadap keputusan pembelian.

\section{H. Pengaruh Product Knowledge Terhadap Keputusan Pembelian dengan Minat Beli Sebagai Variabel Intervening}

Dari hasil analisis jalur, didapatkan t hitung sebesar 2,342 lebih besar dari t tabel 1,66055 dengan signifikansi 5\% sehingga dapat diartikan koefisien mediasi 0,403712 adalah signifikan. Hal tersebut menunjukkan bahwa minat dapat memediasi 
Website : http://ekomaks.unmermadiun.ac.id

pengaruh product knowledge terhadap keputusan pembelian. Sehingga hipotesis pengaruh product knowledge terhadap keputusan pembelian dengan minat beli sebagai variabel intervening diterima. Hasil penelitian ini relevan dengan hasil penelitian sebelumnya yang dilakukan oleh Masfufah (2019) dan Prasetyo (2020) yang menunjukkan minat dapat memediasi pengaruh pengetahuan terhadap keputusan pembelian.

\section{Pengaruh Religiosity Terhadap Keputusan Pembelian dengan Minat Beli Sebagai Variabel Intervening}

Berdasarkan hasil analisis jalur, didapatkan nilai t hitung yaitu 0,0103 kurang dari t tabel 1,66055 dengan signifikansi 5\%. Maka dapat disimpulkan koefisien mediasi 0,11036 tidak signifikan, sehingga minat tidak memiliki pengaruh mediasi pada pengaruh religiosity terhadap keputusan pembelian. Sehingga hipotesis pengaruh religiosity terhadap keputusan pembelian dengan minat beli sebagai variabel intervening ditolak. Hasil penelitian ini relevan dengan hasil penelitian sebelumnya yang dilakukan oleh Lutfia (2020) dan Safitri (2019) yang menunjukkan variabel minat tidak dapat memediasi pengaruh religiusitas terhadap keputusan pembelian.

\section{J. Pengaruh Islamic Advertising Ethics Terhadap Keputusan Pembelian dengan Minat Sebagai Variabel Intervening}

Berdasarkan hasil analisis jalur, didapatkan nilai t hitung yaitu sebesar 4,3076 leih dari t tabel 1,66055 dengan signifikansi 5\%. Maka dapat disimpulkan bahwa koefisien mediasi 0,20068 signifikan. Jadi dapat disimpulkan bahwa terdapat pengaruh mediasi dari variabel minat beli pada pengaruh islamic advertising ethics terhadap keputusan pembelian. Hal ini menunjukkan bahwa etika periklanan islami dapat mendorong minat responden hingga timbulnya keputusan untuk membeli produk kosmetik tersebut. Sehingga hipotesis pengaruh islamic advertising ethics terhadap keputusan pembelian dengan minat beli sebagai variabel intervening diterima. Hasil penelitian ini relevan dengan hasil penelitian sebelumnya yang dilakukan oleh Prihanti (2019) dan Ulfah (2020) yang menunjukkan bahwa islamic advertising ethics memiliki pengaruh terhadap minat beli dan keputusan pembelian.

\section{KESIMPULAN DAN SARAN}

A. Kesimpulan

1. Tidak terdapat pengaruh product knowledge terhadap keputusan pembelian produk kosmetik wardah di Kota Salatiga. Hasil ini berdasarkan hasil uji t yang menunjukkan nilai signifikansi sebesar 0,998 lebih besar dari 0,05.

2. Tidak terdapat pengaruh religiosity terhadap keputusan pembelian produk kosmetik wardah di Kota Salatiga. Hasil ini berdasarkan hasil uji t yang menunjukkan nilai signifikansi sebesar 0,186 lebih dari 0,05.

3. Tidak terdapat pengaruh islamic advertising ethics terhadap keputusan pembelian produk kosmetik wardah di Kota Salatiga. Hasil ini berdasarkan hasil uji t yang menunjukkan nilai signifikansi sebesar 0,067 lebih besar dari 0,05.

4. Terdapat pengaruh yang signifikan dari product knowledge terhadap minat pembelian produk kosmetik wardah di Kota Salatiga. Hasil ini berdasarkan hasil dari uji t yang menunjukkan nilai signifikansi sebesar 0,000 lebih kecil dari 0,05.

5. Tidak terdapat pengaruh religiosity terhadap minat pembelian produk kosmetik wardah di Kota Salatiga. Hasil ini berdasarkan hasil uji t yang menunjukkan nilai signifikansi sebesar 0,919 lebih besar dari 0,05.

6. Terdapat pengaruh islamic advertising ethics terhadap minat pembelian produk kosmetik wardah di Kota Salatiga. Hasil ini berdasarkan hasil uji t yang menunjukkan nilai signifikansi sebesar 0,000 lebih kecil dari 0,05.

7. Terdapat pengaruh minat beli terhadap keputudan pembelian produk kosmetik wardah di Kota Salatiga. Hasil ini berdasarkan hasil uji t yang menunjukkan nilai signifikansi sebesar 0,000 lebih kecil dari 0,05.

8. Terdapat pengaruh mediasi minat beli pada pengaruh product knowledge terhadap keputusan pembelian produk kosmetik wardah di Kota Salatiga. Hasil ini berdasarkan hasil analisis jalur yang menunjukkan nilai t hitung sebesar 2,342 lebih besar dari t tabel 1,66055 dengan signfikansi 5\%.

9. Tidak terdapat pengaruh mediasi dari variabel minat beli pada pengaruh religiosity terhadap keputusan pembelian produk kosmetik wardah di Kota Salatiga. Hasil ini berdasarkan hasil analisis jalur yang menunjukkan niali t hitung sebesar 0,0103 lebih kecil dari t tabel 1,66055 dengan signifikansi 5\%.

10. Terdapat pengaruh mediasi dari variabel minat beli pada pengaruh islamic advertising ethics terhadap keputusan pembelian produk ksometik wardah di Kota Salatiga. Hasil ini berdasarkan hasil analisis jalur yang menunjukkan nilai t hitung sebesar 4,3076 lebih besar dari t tabel 1,66055 dengan signifikansi $5 \%$.

B. Saran

Diharapkan peneliti selanjutnya yang ingin meneliti dengan variabel yang serupa dapat memperluas studi kasus penelitiannya. Kemudian diharapkan penelitian selanjutnya dapat lebih bervariasi lagi dalam pengambilan variabel independen maupun dependen, mengingat banyak faktor-faktor lain yang dapat mempengaruhi keputusan pembelian selain faktor yang telah disebutkan dalam penelitian ini.

\section{III.DAFTAR PUSTAKA}

Adiba, E. M., Wulandari, D. A., \& Surabaya, S. P. (2018). Pengaruh Halal Knowledge , Islamic Religiosity , dan Attitude terhadap Behavior Konsumen Muslim Generasi Y Pengguna Kosmetik Halal di Surabaya. Jurnal Inovasi Bisnis Dan Manajemen Indonesia, 1(3).

Adinugraha, H. H., \& Sartika, M. (2019). Halal Lifestyle Di Indonesia. An-Nisbah: Jurnal Ekonomi Syariah, 5(2), 57-81. https://doi.org/10.21274/an.2019.5.2.layout

Cader, A. C. (2015). Islamic challenges to advertising: A Saudi Arabian perspective. Journal of Islamic Marketing, 6(2), $166-187$. https://doi.org/10.1108/JIMA-03-2014-0028 
Website : http://ekomaks.unmermadiun.ac.id

Ferdinand, A. (2011). Metode Penelitian Manajemen: Pedoman Penelitian untuk Penulisan Skripsi, Tesis, dan Disertasi Ilmu Manajemen. Badan Penerbit Universitas Diponegoro.

Ghani, E., \& Ahmad, B. (2015). Islamic advertising ethics violation and purchase intention Eesha Ghani * and Basheer Ahmad. Journal Islamic Marketing and Branding, 1(2), 22-24.

Ghozali, I. (2011). Aplikasi Analisis Multivariate dengan Program IBM SPSS 19. Badan Penerbit Universitas Diponegoro.

Glock, C. Y., \& Stark, R. (1965). Religion and Society in Tension. Rand mcNally Company.

Ikhsan, R. R. N., \& Sukardi. (2020). Pengaruh Religiusitas, Sikap, Norma Subjektif, dan Kontrol Perilaku terhadap Niat Membeli Produk Kosmetik Halal di Fakultas Ekonomi dan Bisnis Universitas Ahmad Dahlan Yogyakarta. Jurnal Ilmiah Ekonomi Global Masa Kini, 11(01), 49-55.

Imamuddin, M. (2017). Pengaruh Label Halal dan Religiusitas Terhadap Keputusan Pembelian Mi Instan Mahasiswa IAIN Bukittinggi T.A 2016/2017. Journal of Economic Studies, 1(1).

Jayanegara, K. W., \& Najib, M. F. (2020). Pengaruh Simbol Religi Periklanan terhadap Minat Beli Konsumen. Prosiding Industrial Research ..., $26-27$. https://jurnal.polban.ac.id/proceeding/article/view/2143

Kotler, P., \& Keller, K. L. (2009). Manajemen Pemasaran (A. Maulana \& W. Hardani (eds.); ke-13). Jakarta: Erlangga.

Kotler, P., \& Keller, K. L. (2012). Marketing Management (14th ed.). New Jersey: Prentice Hall.

Lutfia, A. (2020). Pengaruh Religiusitas, Produk dan Citra Bank Terhadap Keputusan Nasabah Untuk Menabung di BPRS Artha Amanah Ummat Unggaran dengan Minat Sebagai Variabel Intervening. SKRIPSI. Salatiga: Fakultas Ekonomi Dan Bisnis Islam IAIN Salatiga.

Maghfiroh, S. (2018). Pengaruh Religiusitas, Pendapatan, dan Lingkungan Sosial Terhadap Minat Menabung di Bank Syariah pada Santri Pesantren Mahasiswi Darush Shalihat. Jurnal Pendidikan Dan Ekonomi, 7(2), 213-222.

Maharani, N. K., \& Silvia, A. (2019). Analisis Pengaruh Pengetahuan dan Religiusitas Terhadap Niat Pembelian Produk Kosmetik Halal. : : Jurnal Ekonomi Syariah Dan Filantropi Islam, 3(1).

Mahendra, R. (2020). Pengaruh Country Of Origin, Product Knowledge dan citra Merk Terhadap Keputusan Pembelian Laptop HP di Kota Padang. SKRIPSI. Padang: Universitas Bung Hatta.

Masfufah, U. (2019). Pengaruh Pengetahuan Nasabah, Tingkat Religiusitas dan Tingkat Pendapatan Terhadap Keputusan Menjadi Nasabah di Bank Syariah Dengan Minat Sebagai Variabel Pemediasi (Studi Ksusu Bank BRI Syariah KCP Magelang). In Journal of Chemical Information and Modeling (Vol. 01, Issue 01).

Mutaqin, A. (2013). Konsep Periklanan Dalam Ekonomi Islam. Cahaya Aktiva, 03(01), 1-10.

Mutiara, I., \& Syahputra. (2018). Pengaruh Pengetahuan Produk dan Produk Halal Terhadap Keputusan Pembelian pada Produk Kecantikan Korea. Jurnal Indonesia Membangun, 17(2).

Nasution, M. Y. (2020). European Journal of Management and Marketing Studies The Influence Of Product Knowledge On Atittude And Interest In Buying Halal Product. European Journal of Management and Marketing Studies, 5(3). https://doi.org/10.46827/ejmms.v5i3.876

Nuraeni, D. (2020). Pengaruh Pengetahuan Produk dan Harga Terhadap Keputusan Pembelian Hijab Rabbani (Penelitian Pada Masyarakat Kaum Perempuan Di Kecamatan Cibitung Bekasi). Jurnal Ilmu Ekonomi Syariah, 2(1).

Nurfadilah, N. F., Bayuni, E. M., \& Srisusilawati, P. (2020). Pengaruh Iklan terhadap Minat Beli pada Produk Rabbani di Purwakarta. Hukum Ekonomi Syariah, 6(2), 773-790.

Peter, J. P., \& Olson, J. C. (2010). Consumer Behavior \& Marketing (9th ed.). McGraw-Hill Companies Inc.

Pradani, E. Y., \& Iriani, S. (2018). Pengaruh Religiusitas dan Country Of Origin terhadap Keputusan Pembelian Mie Samyang (Studi pada Konsumen Mie Samyang di Surabaya Pusat). Jurnal Manajemen-Fakultas Ekonomi, 2(3). www.republika.co.id,

Prasetyo, A. (2020). Pengaruh Pengetahuan Bank Syariah, Promosi, dan Fasilitas Terhadap Keputusan Menabung di Bank Syariah dengan Minat Menabung Sebagai Variabel Intervening (Studi kasus pada Masyarakat Desa Pasuruhan, Mertoyudan, Magelang). SKRIPSI. Salatiga: Fakultas Ekonomi Dan Bisnis Islam IAIN Salatiga.

Prihanti, D. (2019). Pengaruh E-Service Quality, Islamic Branding dan Islamic Advertising Ethics terhadap Keputusan Pembelian (Studi Kasus pada Konsumen Shopee di Indonesia). SKRIPSI. Salatiga: Fakultas Ekonomi Dan Bisnis Islam IAIN Salatiga. http://e-repository.perpus.iainsalatiga.ac.id/id/eprint/5645

Safitri, A. (2019). Pengaruh Harga, Promosi Dan Religiusitas Terhadap Keputusan Masyarakat Dalam Memilih Bank Syariah Dengan Minat Sebagai Variabel Intervening. In SKRIPSI. Salatiga: Fakultas Ekonomi dan Bisnis Islam IAIN Salatiga.

Solihin, D. (2020). Pengaruh Kepercayaan Pelanggan Dan Promosi Terhadap Keputusan Pembelian Konsumen Pada Online Shop Mikaylaku Dengan Minat Beli Sebagai Variabel Intervening. Jurnal Mandiri : Ilmu Pengetahuan, Seni, Dan Teknologi, 4(1), 38-51. https://doi.org/10.33753/mandiri.v4i1.99

Sudarti, K., \& Ulum, S. B. (2019). Peran Sikap Konsumen dalam Memediasi Pengaruh Religiusitas dan Reputasi Merek Terhadap Minat Beli Ulang. In EKOBIS (Vol. 20, Issue 2).

Sumarwan, U. (2014). Perilaku Konsumen Teori dan Penerapan dalam Pemasaran. Ghalia Indonesia.

TBI. (2021). Top Brand Award. Retrieved from Top Brand Award: https://www.topbrand-award.com/top-brand-index.

Ulfah, N. C. (2020). Pengaruh Muslimah Endorser, Kualitas Produk dan Islamic Advertising Ethics Terhadap Keputusan Pembelian dengan Minat Beli Sebagai Variabel Intervening (Studi Kasus Pada Konsumen Produk Wardah di Salatiga). Salatiga: IAIN Salatiga. SKRIPSI.

Ulya, M. M. (2020). Pengaruh Knowledge , Brand Image Dan Brand Trust Terhadap Keputusan dengan Minat sebagai Variabel Intervenig. SKRIPSI. Salatiga: Fakultas Ekonomi Dan Bisnis Islam IAIN Salatiga.

Wulansari, E. (2020). Pengaruh Tingkat Religiusitas, Reputasi Dan Persepsi Nasabah Terhadap Keputusan Memilih BANK Syariah dengan Minat Sebagai Variabel Intervening (Studi Kasus Masyarakat Salatiga). SKRIPSI. Salatiga: Fakultas Ekonomi Dan Bisnis Islam IAIN Salatiga.

Zulkifli, Z. Bakhri, B. S. \& Melina, F. (2019). Pengaruh Periklanan Islami Terhadap Keputusan Pembelian Produk Shampoo Hijab Sunsilk Clean and Fresh Pada Mahasiswa Universitas Islam Riau. Journal of Management and Bussines, 1(1), 59-73. 